\title{
Design of financial statement preparation based on SAK EMKM using microsoft excel
}

\author{
Ifa Rosania Afif, ${ }^{1}$ Nawirah $^{2}$ \\ 1,2Universitas Islam Negeri Maulana Malik Ibrahim Malang, Indonesia \\ email: levha.afifa@gmail.com
}

\begin{abstract}
Purpose - Micro, Small and Medium-sized Enterprises (MSMEs) are a pillar of the Indonesian economy, as evidenced by the ability of MSMEs to save the economy in Indonesia during the monetary crisis in 1998. There was a significant increase in the number of MSMEs in Indonesia, inseparable from the problems that caused the failure of MSME actors. Among the affecting factors are the simple management, lack of supervision of the production process and the quality caused by the system on the entity, the simple recording of financial statements, and limited market access. The purpose of this study is to facilitate the MSMEs XXX in preparing financial statements based on SAKEMKM using Microsoft Excel software.

Method - This research uses a qualitative approach. The location of this research is MSMEs XXX which is located on Sunan Muria II Street No. 16 Malang. The data collection uses observation and interview techniques directly to researchers, the analytical method used is hermeneutics which means an approach to analyze and interpret data centered on the meaning of qualitative data.
\end{abstract}

Result - The design of financial report preparation based on SAK EMKM using Microsoft Excel in MSMEs XXX includes income statement, financial position report, and notes on financial statements. The MSMEs found problems in preparing the financial statements because of the lack of adequate resources and supporting software.

Implication - UMKM $\mathrm{xxx}$ is expected to be able compile financial statements based on SAKEMKM with microsoft excel software.

Originality - This research is the first study at UMKM xxx by making financial reports based on SAKEMKM with microsoft excel software.

Keywords: MSMEs; financial statements; software 
Ifa Rosania Afif, Nawirah

\section{Introduction}

Micro, Small and Medium-sized Enterprises (MSMEs) are a pillar of the Indonesian economy, as evidenced by the ability of MSMEs to save the JIAFR | 142 economy in Indonesia during the monetary crisis in 1998. There was a significant increase in the number of MSMEs in Indonesia, inseparable from the problems that caused the failure of MSME actors. Among the affecting factors are the simple management, lack of supervision of the production process and quality caused by the system on the entity, the simple recording of financial statements, and limited market access.

Hapsari et al. (2016) in their study explained that the results of a survey of 45 respondents found that only $51 \%$ of the respondents booked their business and those according to the needs of creditors were only $15.5 \%$. The factors causing the small percentage of MSMEs that do the records in accordance with the needs of the steakholders are because they are not accustomed to recording and their poor understanding of financial statements. Therefore, it can be seen that MSMEs really need a simple tool in helping the preparation of financial statements.

The results of the researchers' interview with the owner can be concluded that the MSMEs XXX has attempted to prepare financial reports as an evaluation material for the owners, also intended for external parties who need it, but the MSMEs XXX is constrained by the lack of the available human resources and the less supportive system. MSMEs XXX did not prepare financial statements based on SAK EMKM (Financial Accounting Standard for Micro, Small, and Medium Entities), so researchers were interested in doing this research, because since the establishment of MSMEs XXX in 2011 until now, it was constrained by Human Resources (HR) in the preparation of financial statements.

We already know that financial statements are a very important element for the sustainability of business undertaken by MSMEs XXX which focuses on making headscarves, mukena, apparels, sandals, and screen printing. With the design carried out by researchers, it is hoped that it can facilitate MSMEs XXX 
in preparing financial reports, so that the existence of financial reports in accordance with SAK EMKM standards can make it easier for MSMEs XXX to know its performance and can significantly increase the development of MSMEs XXX. In addition, it can also help the MSMEs to propose financing to banks.

\section{Literature Review}

\section{Accounting}

Accounting is an information system that measures business activities, processes data into reports, and communicates results to interested parties in decision making. Accounting is also a "business language" because with accounting most business information is communicated. The company distributes accounting reports that summarize the company's financial performance to owners, creditors, the government and potential investors (Jusup, 2011).

\section{Financial Report}

Financial statements are basically the results of an accounting process that can be used as a tool to communicate financial data or company activities to interested parties. IAI (Indonesian Accountants Association) in SAK EMKM states that the purpose of financial statements is as a provider of information on the financial position and financial performance of an entity that is useful for users in economic decision making. These financial statements are the responsibility of management to internal and external parties. In accordance with SAK EMKM, financial statements for micro, small and medium enterprises consist at least of: (1) Financial Position Report, (2) Income Statement, (3) Notes to the Financial Statements.

In more detail, Hery (2015) writes down the stages in the accounting cycle as follows: (1) First the transaction supporting data is analyzed and the information contained in the document is recorded in a journal. (2) Then the accounting data in the journal is posted in the ledger. (3) All final balances contained in each foreign ledger account are posted to the trial balance to 
Ifa Rosania Afif, Nawirah

match the overall value of the account with normal balance and the overall value of the account with the credit balance. (4) Analyze the adjustment data and make adjusting entry according to the cost allocation to the operation function. (5) Post the adjusting journal data to each relevant ledger. (6) By using lane balance assistance options as a worksheet, the trial balance after adjustments and financial statements are prepared. (7) Make closing journal entries for production boarding posts and then close the general book. (8) Post closing journal data to each related account ledger. (9) Prepare a trial balance after closing. (10) Make reversing entries.

\section{Microsoft Excel}

Microsoft Excel is a spreadsheet application program or electronic worksheets. This application displays the table sheets created by Microsoft Corporation for Windows and Mac OS operating systems. It is very easy to operate so that Microsoft Excel becomes one of the popular computer programs for the users (Badriyah, 2014).

\section{MSMEs}

Table 1. Characteristics of MSMEs

\begin{tabular}{|c|c|c|c|}
\hline Description & $\begin{array}{l}\text { Micro business } \\
\text { Enterprises }\end{array}$ & $\begin{array}{l}\text { Small business } \\
\text { Enterprises }\end{array}$ & $\begin{array}{l}\text { Medium business } \\
\text { Enterprises }\end{array}$ \\
\hline Net worth & $\begin{array}{l}\text { Max. Rp } 50 \\
\text { million }\end{array}$ & $\begin{array}{l}\text { Max. Rp } 500 \\
\text { million }\end{array}$ & $\begin{array}{l}\text { Rp } 500 \text { million - Rp } \\
10 \text { billion }\end{array}$ \\
\hline Annual Sales & $\begin{array}{l}\text { Max. Rp } 300 \\
\text { million }\end{array}$ & $\begin{array}{l}\text { Max. Rp 2,5 } \\
\text { billion }\end{array}$ & $\begin{array}{l}\text { Rp 2,5 billion - Rp } \\
50 \text { billion }\end{array}$ \\
\hline Owner & $\begin{array}{l}\text { Individual or legal } \\
\text { entity }\end{array}$ & $\begin{array}{l}\text { Individual/legal } \\
\text { entity and not } \\
\text { affiliated with } \\
\text { medium or large } \\
\text { businesses }\end{array}$ & $\begin{array}{l}\text { Individual/legal } \\
\text { entity and not } \\
\text { affiliated with } \\
\text { medium or large } \\
\text { businesses }\end{array}$ \\
\hline Status & Independent & Independent & Independent \\
\hline Business Form & Free & Free & Free \\
\hline Regulation & $\begin{array}{l}\text { The latest MSMEs } \\
\text { Law }\end{array}$ & $\begin{array}{l}\text { The latest MSMEs } \\
\text { Law }\end{array}$ & $\begin{array}{l}\text { The latest MSMEs } \\
\text { Law }\end{array}$ \\
\hline
\end{tabular}

Source: Alternative Financing Book 
Design of financial statement preparation ...

\section{Research Methods}

This research is a qualitative research. Qualitative is a research that tries to understand the phenomenon in its natural setting and context (Sarosa, 2012). To collect the primary data, the researchers go directly to the location for direct observation of how conditions in the field regarding the activities JIAFR | 145 carried out in the production process, observing the assets owned, and transactions that occur. In addition, researchers also conducted interviews directly to the owners and employees of MSMEs XXX.

In this study, there are also secondary data to support the primary data which include SAK EMKM as a standard for preparing financial reports, software design manuals, books on accounting, and sales notes from October to December as proof of transactions at MSMES XXX. The data collection techniques used direct interview and observation.

The data analysis was carried out through the following procedure: (1) Collecting data that have been obtained, either primary data obtained directly or secondary data from transactions done by MSMEs XXX. (2) Review all data obtained from interviews or observations and the secondary data from MSMEs XXX. From all data obtained, then they were interpreted in accordance with the accounting cycle and based on the applicable SAK EMKM. (3) From the data that have been collected, the researchers can explain the type of entity carried out by MSMEs XXX. Transactions that occur can be sorted into financial statements in accordance with standards that have been issued by IAI with the help of Microsoft Excel.

\section{Results and Discussion}

This research was conducted to facilitate the MSMEs XXX by designing simple software based on SAK EMKM. The procedure explained above is an elaboration of the design of financial statement preparation based on SAK EMKM with the help of a very simple software, that is Microsoft Excel. Based on the interview, MSMEs XXX has not yet prepared financial statements in accordance with the implemented SAK EMKM. Transactions that occur on 
Ifa Rosania Afif, Nawirah

activities carried out by MSMES XXX are usually recorded by writing income and expenses.

From the results of the interview with the MSMEs XXX manager, it can be concluded that the recording carried out by the MSMEs XXX is still very simple, only about sales, income for tailoring services and purchasing services when there are shortages during the production process and delivery costs.

Almira Handmade Malang MSMEs has not yet prepared financial reports in accordance with the existing SAK EMKM. In accordance with SAK EMKM, financial statements for micro, small and medium enterprises consist at least of:

\section{Income statement}

Income statement is a report which presents the income and expenses for the period. The margin between materials and income will be profit/loss for the period. The accounts on the income statement are: (1) Revenue, (2) Financial cost, (3) Tax cost.

Table 2. Income Statements

\begin{tabular}{|c|c|c|c|}
\hline \multirow{3}{*}{\multicolumn{4}{|c|}{$\begin{array}{c}\text { MSMEs XXX } \\
\text { Income Statements } \\
\text { October - December } 2018\end{array}$}} \\
\hline & & & \\
\hline & & & \\
\hline \multicolumn{2}{|l|}{ Sales } & $\mathrm{Rp}$ & $91,253,000$ \\
\hline \multicolumn{2}{|l|}{ Sales return } & $\mathrm{Rp}$ & $(75,000)$ \\
\hline \multicolumn{2}{|l|}{ Net sales } & $\mathbf{R p}$ & $91,178,000$ \\
\hline \multicolumn{2}{|l|}{ Cost of goods sold } & $\mathbf{R p}$ & $(79,414,000)$ \\
\hline \multicolumn{2}{|l|}{ Groos profit } & $\mathbf{R p}$ & $11,764,000$ \\
\hline \multicolumn{2}{|l|}{ Tailoring service income } & $\mathrm{Rp}$ & $4,514,000$ \\
\hline \multirow[t]{4}{*}{ Operating expenses: } & & $\mathrm{Rp}$ & \\
\hline & Incentive expenses & $\mathrm{Rp}$ & 1.000 .000 \\
\hline & $\begin{array}{l}\text { Vehicles depreciation } \\
\text { expanse }\end{array}$ & $\mathrm{Rp}$ & 6.325 .000 \\
\hline & Equipment depreciation & $\mathrm{Rp}$ & 900,000 \\
\hline
\end{tabular}


Total operating

expenses

Net income

expanse

Gas/transportation

expenses

Toll expenses
Rp 3,558,000

Rp 64,000

Rp $(11,847,000)$

Rp $\quad 4,431,000$

Source: Processed by researchers

\section{Financial Position Report}

Financial statements are a systematic report that describes the assets, liabilities, and capital of an entity to describe the financial position. The following are related accounts in the statement of financial position: (1) Cash and cash equivalents, (2) Receivables, (3) Inventory, (4) Fixed assets, (5) Business debt, (6) Bank debt, (7) Equity.

In accordance with SAK EMKM, the applicable design made by the researchers concerning the statement of financial position at MSMEs XXX is as follows in table 3.

Table 3. Financial Position Report

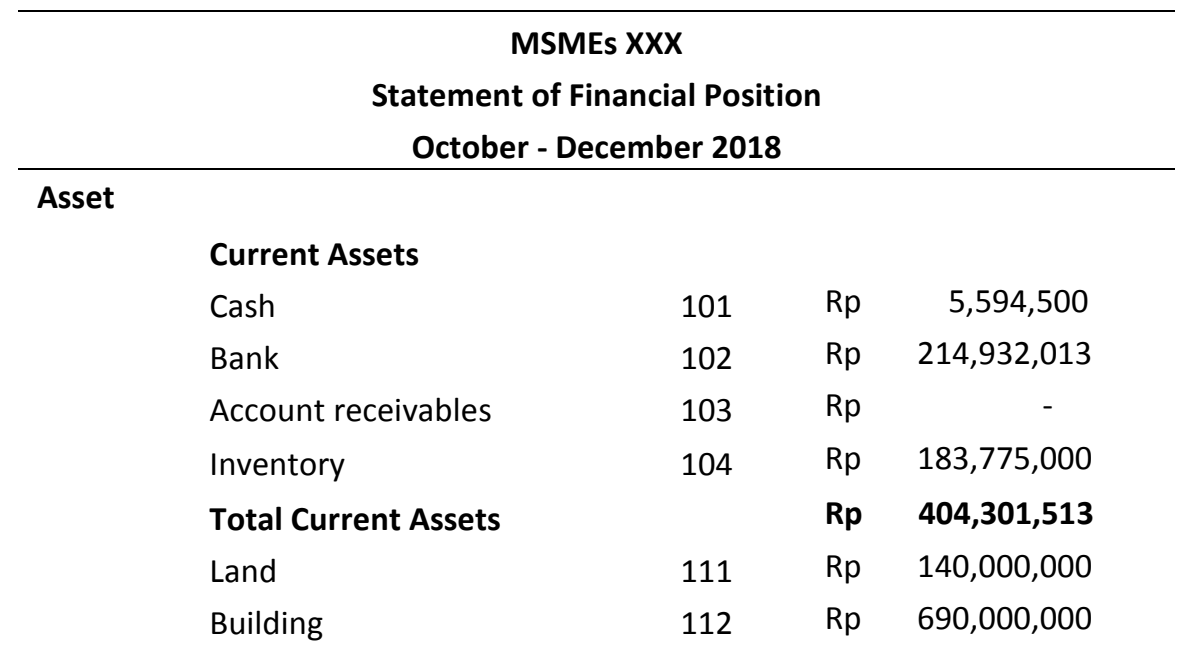


Ifa Rosania Afif, Nawirah

JIAFR | 148

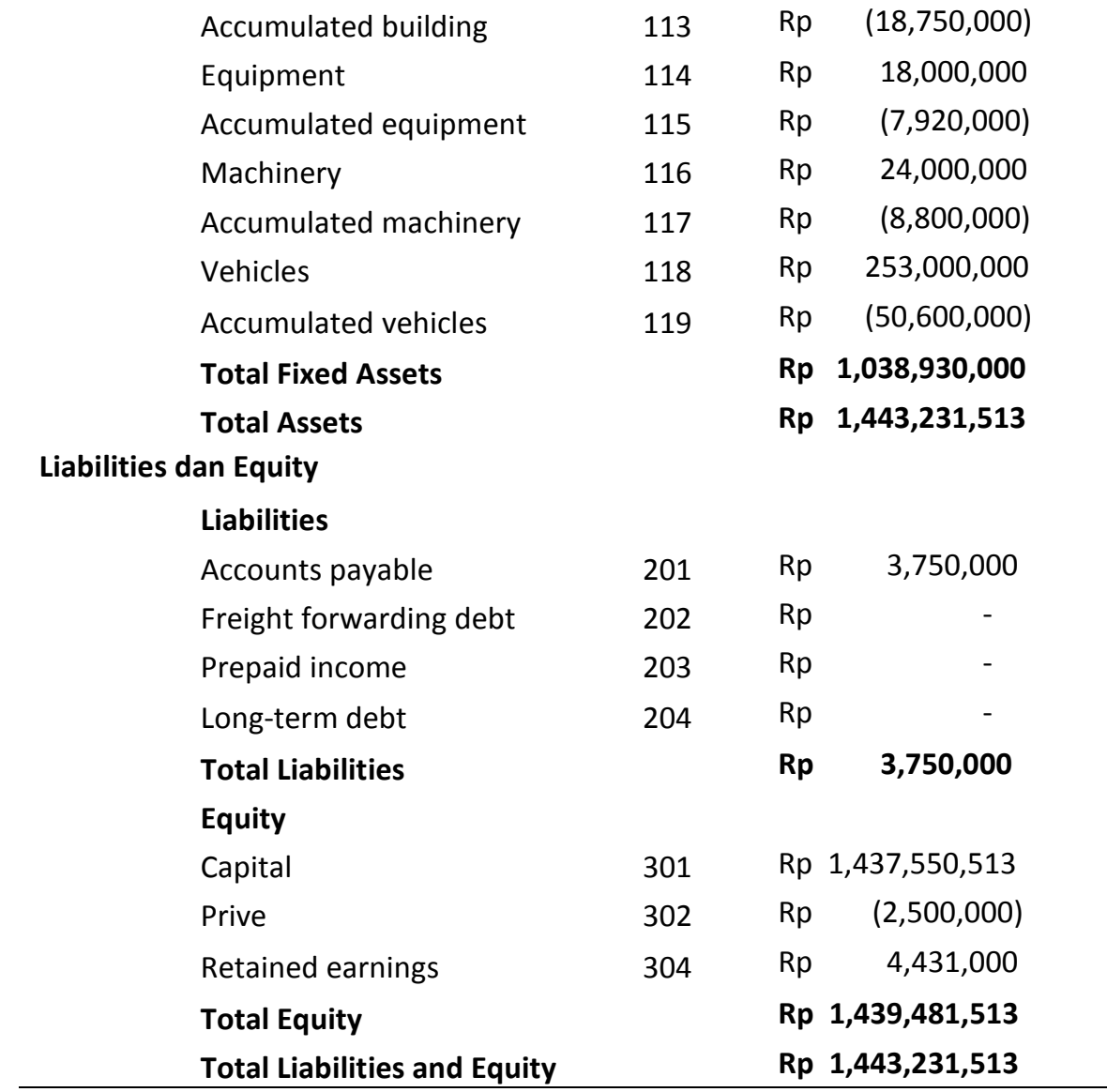

Source: Processed by researchers

\section{Notes to the Financial Statements}

In accordance with SAK EMKM, the notes to the financial statements contain: (1) A statement that the financial statements have been prepared in accordance with SAK EMKM. (2) Overview of economic policies. (3) Additional information and certain account details that explain important transactions and material so that it is useful for users to understand financial statements. 
Design of financial statement preparation ...

Below is a note to the Financial Statements that have been made by the researchers can see in table 4 .

Table 4. Notes to the Financial Statements

MSMEs XXX

JIAFR | 149

\section{Note to the Financial Statements}

October - December 2018

\section{General}

Almira Handmade Malang was founded in 2016. It works on manufacturing industry. The industry has obtained a permit from the Integrated Licensing Services Agency of Kota Malang with number: 517/3/35.37.407/2014. This industry has met the criteria as a Micro, Small and Medium Entity in accordance with Law Number 20 Year 2008. This industry is domiciled on Jalan Sunan Muria II No 16 Malang.

\section{Overview Accounting Policies}

a. Compliance Statement

The Financial Statements of MSME Almira Handmade Malang have not met the Financial Accounting Standard for Micro, Small, and Medium Entities.

b. Basis of Preparation

The basis of financial statements preparation of MSME Almira Handmade Malang is cash notes, purchase notes, raw material and indirect material, production notes, sales notes, production labor salary notes and operational cost notes. The currency used in the financial statements is rupiah.

c. Inventory

The raw material inventory costs include purchasing costs and purchasing transport costs. The conversion costs include direct labor costs and overhead. Recording method done by MSME yang Almira Handmade Malang is still simple so that it has not presented the actual invetories.

d. Fixed Assets

Fixed Assets owned by MSME Almira Handmade Malang have not been recorded as much the gaining costs even though the assets are legally owned by the entity. The entity also has not depreciated the existing fixed assets. 
Ifa Rosania Afif, Nawirah

\section{e. Recognition of Revenue \& Expenses}

Sales revenue is recognized when the bill is issued or the product delivery is done to the customers.

JIAFR | 150

\section{Cash}

Cash owned by MSME Almira Handmade Malang is divided into two; cash and bank cash.

October - December 2018

Petty cash

Rp 5,594,500

Cash BRI Bank

Rp 57,221,117

Cash BNI Bank

Rp 90,568,795,24

Cash BCA Bank

Rp 25,677,508,18

Cash Muamalat Bank Rp 30,995,532

Cash Mandiri Bank Rp 10,509,000

\section{Liabilities}

Accounts Payable What happened at Almira Handmade Malang UMKM was because of the Cut Off occurring on December 27, 2018 so that business debts arose from the adjustment of employee salaries.

October - December 2018

Rp 3,750,000

\section{Sales}

Sales activities done by MSME Almira Handmade Malang are in cash with the following details:

October - December 2018

Sales

Rp 91,253,000

Return

$\operatorname{Rp} \quad(75,000)$

Net income

Rp $91,178,000$

Source: Processed by researchers

\section{Conclusion}

Based on the results of the design of financial statements based on SAK EMKM using Microsoft Excel, it can be concluded as follows:

Practically, MSMEs XXX only records the cash in and cash out, and also there is a transfer of production processing and production has been completed. It can be seen that the MSMEs has not recorded in accordance with SAK EMKM because in SAK EMKM reporting there are at least three 
parts: income statement, statement of financial position, and notes to financial statements. The draft of financial report preparation was made by the researchers to facilitate MSMEs XXX in compiling reports in accordance with the accounting cycle and Financial Accounting Standards for Micro, Small and Medium Enterprises. It is started with journaling, then entering into a ledger, and in the end of the period, adjustments are made. Then the adjustments are entered into the ledger. The financial statements preparation is assisted with work papers or work sheet, then it becomes a financial report which includes income statement, statement of financial position, and notes to financial statements.

The problems faced by MSMEs XXX in the preparation of financial statements are the absence of adequate human resources (HR) in the financial sector and there is no software that can be used in preparing financial statements.

\section{References}

Aziz, dkk. (2009). Alternative Pembiayaan terhadap UMKM melalui Pasar Modal di Indonesia, Jakarta: Centre for Finance, Investment and Securities Law (CFISEL).

Ghony, M. D., \& Almansyur, F. (2012). Metodologi Penelitian Kualitatif, Jogjakarta: Ar-Ruzz Media.

Hapsari, R. K., dkk. (2016). Perancangan dan Pengembangan Pengelolaan Keuangan UMKM Berbasis Sistem Informasi.

Harahap, S. S. (2012). Teori Akuntansi, Jakarta: Rajawali Pers.

Hery. (2015). Pengantar Akuntansi, Jakarta: PT. Grasindo.

Hubais, M. (2009). Prospek Usaha Kecil dalam Wadah Kubator Bisnis, Ghalia Indonesia.

IAI. (2016). Exposure Draft Standar Akuntansi Keuangan Entitas Mikro Kecil dan Menengah, Jakarta: DSAK IAI.

Jusup, A. H. (2011). Dasar-Dasar Akuntansi, Yogyakarta: STIE YKPN.

Kieso, W., \& Warfield. (2018). Akuntansi Keuangan Menengah, Jakarta: Salemba Empat. 
Ifa Rosania Afif, Nawirah

Krisdiartiwi, M. (2008). Pembukuan Sederhana Untuk UKM, Jakarta: Med Press.

Nurlela \& Elvia, H. (2016). Penerapan Laporan Keuangan Usaha Kecil Menengah berbasis SAK ETAP pada Toko Jamu Nikisami, 5(2).

Purwanti, E. (2017). Analisis Pengetahuan Laporan Keuangan pada Industri Konveksi di Salatiga, 10(20).

Putra, H. A., \& Kurniawati, E. P. (2012). Penyusunan Laporan Keuangan Pada untuk Usaha Kecil dan Menengah Berbasis SAK ETAP.

Rudianto. (2012). Pengantar Akuntansi, Jakarta: Erlangga.

Sarosa, S. (2012). Dasar-Dasar Penelitian Kualitatif, Jakarta: Indeks.

Sekaran, U. (2006). Research Methods for Business, Jakarta: Salemba Empat.

Shonhadji, N., dkk. (2017). Penerapan Penyusunan Laporan Keuangan pada Usaha Kecil Menengah Berbasis SAK EMKM di Surabaya.

Sugiyono. (2013). Metode Penelitian Bisnis, Bandung: Alfabeta.

Suwardjono. (2003). Akuntansi Pengantar, Yogyakarta: BPFE.

Tatik. (2018). Implementasi SAK EMKM (Standar Akuntansi Keuangan Entitas Mikro, Kecil, dan Menengah) pada Laporan Keuangan UMKM (Studi Kasus pada UMKM XYZ Yogyakarta), 14(2).

Widjaja, Y. R., dkk. (2018). Penyusunan Laporan Keuangan Sederhana untuk Industri Konveksi, 1(1). 